\title{
Citizenship education in Denmark: reinventing the nation and/or conducting multiculturalism(s)?
}

\author{
Claus Haas* \\ School of Education, University of Aarhus, Denmark
}

\begin{abstract}
In 2007 the concept of citizenship was officially incorporated into teacher education in Denmark, as part of a compulsory subject called 'Christianity studies, life enlightenment, and citizenship'. Thus, at least to some extent, the notion of citizenship is expected to find its way into the educational and political vocabulary of future teachers and pupils/students of the Danish educational system, and probably into the public discussions about the meaning of democratic education in general. The subject itself is only described in very general terms within the legal framework. In order to understand the meaning and purpose of the new subject it is necessary to position it within a broader discourse of citizenship education, as it has been launched by the Danish nation state since 1999. First, citizenship education seems to be exclusively about responding to cultural diversity; secondly, articulated as part of a nation state driven strategy of the sociocultural integration of foreigners, migrants and ethnic minorities. From this follow the questions: What does integration mean, and integration into what? I will make use of four different versions of multiculturalism as my analytical framework - assimilationism, cosmopolitanism, fragmented pluralism, interactive pluralism, and pointing to the fact that the first seems to be the hegemonic understanding of the purpose of citizenship education.
\end{abstract}

Keywords: citizenship education; identity politics; multiculturalism(s); policy discourse analysis

\section{Introduction}

Seen from the perspective of citizenship education the year 2007 is a remarkable year. For the first time the concept 'citizenship' (medborgerskab) was used within the legal framework of the Danish educational system. Citizenship education is going to be implemented as part of the newly reformed teacher education in Denmark, coming into force in 2007. The reform introduces a new compulsory subject called Kristendomskundskab, livsoplysning og medborgerskab ('Christianity studies, life enlightenment and citizenship'). This initiative signifies that citizenship is supposed to be an important element of the democratic vocabulary of Danish teachers, and pupils of the Danish primary school. But what are the intentions behind this conceptual and curricula innovation? Why did the Danish nation state find it necessary to introduce the concept 'citizenship' in this context? In order to answer these questions there isn't much help to be had from studying the legal framework of the subject. The content and identity of the new subject is described only in very general terms. ' It is stated that the aim of subject is general qualification, which regards normative and educational questions from the perspective of studies of religion, the history of ideas and citizenship. These three conceptual pillars of the subject are further connected to a very broad semantic field of concepts that in general terms could be said to constitute the international discourse of citizenship education and citizenship studies such as: different religions,

\footnotetext{
*Email: haas@dpu.dk 
European ideas from antiquity to the present, tradition and modernity, human rights, democracy, the welfare state, equity, freedom of thought, participation, culture, norms and values, and so forth. This listing of concepts that are all relevant in connection to citizenship education do not specify which kind of identity politics underlies the implementation of the subject. Therefore, we have to look elsewhere in order to get a clearer understanding of the meaning and purpose of the new subject. One option is to study the ways in which 'medborgerskab' has been used within the education policies of other nation states.

I want to analyse the discursive and intertextual context within which the agents of the Danish nation state subscribe meaning to the notion of citizenship education. Whether this discourse will have any impact on the future pedagogical practice of teacher training colleges is of course difficult to predict. But when the nation state makes an effort to influence and change the political concepts in use within one of its central cultural institutions, it should be of great interest to educational research. This is due to the fact that citizenship education is closely related to the construction of individual and collective identities, and feelings of belonging. Brubaker and Cooper have pointed out one of the main reasons why nation states find it worthwhile to intervene in this discourse. It has to do with the power of identity politics.

The state might try to monopolize, or try to monopolize not only the legitimate physical force, but also the legitimate symbolic forces. ... This includes the power to name, to identify, to state what is what, and who is who. ... The state is thus a powerful identifier, not because it can create 'identities' in the strong sense - in general it cannot - but because it has the material and symbolic forces to impose categories, classificatory schemes, and modes of social counting and accounting with which bureaucrats, judges, teachers, and doctors must work and to which non-state actors must refer. (Brubaker and Cooper 2000, 15-6)

Seen in this perspective, I understand the aim of citizenship education as a discourse through which the Danish nation state intends to influence and construct the meaning and salience of political and cultural identities within its borders. Just a brief glance at this discourse reveals that one crucial and hegemonic aspect of this endeavour has to do with the fact that Denmark has become a multicultural nation state. In this sense citizenship education is one way to formulate and conduct multiculturalism. So in addition to the questions already raised, I want to highlight the following question: What kinds of multiculturalism inform the official discourse of citizenship education? Before I get into this analysis let me clarify my analytical framework for doing so.

\section{Multiculturalism(s)}

In general terms multiculturalism has two different meanings. First, multiculturalism can be used in a descriptive sense, to describe the existence of different cultures and communities within a society. Secondly, multiculturalism can be used to designate the normative and political response, or rather a set of responses to pervasive and increasing sociocultural diversity in contemporary society (Hartmann and Gerteis 2005, 222). Multiculturalism in this second sense implies the political strategies, discourses and normative doctrines, institutional and organisational arrangements which different social agents consider to be adequate in dealing with cultural diversity. It is this second meaning that I use in this article. Since all societies exhibit cultural diversity to various degrees and depths, multiculturalism, or rather different multiculturalisms, are an integral part of most late-modern political cultures. This is also the case in Denmark, even though the term multiculturalism doesn't figure very often in public debates or within official policy initiatives of the Danish nation state.

I deliberately use multiculturalism in the plural, because we have to be aware of the fact that multiculturalism exists in several partly overlapping, partly competing versions, a crucial point 
made within several studies of multiculturalism (Parekh 2000; Parekh Report 200I; Delanty 2003; Alibhai-Brown 2000; Haas 2003; Hartmann and Gerteis 2005; Kanpol and McLaren 1995). Multiculturalism is rarely, if ever, based on one coherent, all-embracing political theory or vision on how to deal with cultural diversity. Stuart Hall has captured this vital point in our effort to understand the complexity of multiculturalism.

In fact multiculturalism is not a single doctrine, does not characterize one political strategy, and does not represent an already achieved state of affairs. It is not a covert way of endorsing some ideal, utopian state. It describes a variety of political strategies and processes, which are everywhere incomplete. Just as there are different multicultural societies so there are very different multiculturalisms. (Hall 2000, 210)

As we will see below, the multiculturalisms as they are envisioned by the Danish nation state point in different directions, and are flawed by ambiguities. In order to highlight this I make use of discourse analysis of four official documents, within which citizenship education figures in relation to dealing with or responding to cultural diversity within the Danish nation state. By discourse analysis I mean the analysis of the ways in which social agents use texts and language to interpret and construct social realities. In this context discourse analysis is relevant since the concept multiculturalism is neither well-known nor generally used within public discourse. So I have to look for the ways in which multiculturalism is symbolically constructed and represented through 'the talk' about citizenship education. Thus, multiculturalisms are not to be explored as a reality 'out there', multiculturalisms do not in any simple sense reflect or mirror multicultural realities. Rather, I consider the discourse about of citizenship education as one of many sets of signifying practices within which representatives of the Danish nation state (re)produce and represent cultural diversity in order to create and regulate identities and community belonging within the multicultural Danish nation state.

Douglas Hartmann and Joseph Gerteis (2005) have offered a multidimensional theoretical and sociological framework for making such an analysis. They operate with four different theories, or ideal typical models of multiculturalism. I am not going to replicate fully the complexity of their model; in this context some main characteristics of the four approaches seem sufficient.

I. Assimilationism is the vision of cultural diversity that normally is not termed multicultural, since to a large extent cultural diversity is to be removed (Hartmann and Gerteis 2005, 226). In that sense we might say that assimilationism is the opposite of multiculturalism. However, assimilationism is a vision and a strategy that is so closely related to the multicultural questions in general, and more specifically, Hartmann and Gerties note, it is related to fragmented multiculturalism. The main aspiration is to minimize differences because it, at least potentially, constitutes a danger in relation to upholding mutual responsibilities within the social whole, that is within the nation. The social whole or the nation rests on a set of core values which outsiders have to assimilate in order to become full inside members. It is not groups that are expected to assimilate. Rather, full incorporation implies that individuals are expected to shed their previous group identities and to adopt those of the nation (Hartmann and Gerteis 2005, 227). This way of thinking is quite similar to a powerful strand within American political culture - the theory of US as a sociocultural melting pot.

2. Cosmopolitanism emphasises tolerance and individual choice. Group identities are not supposed be the source of public rights or obligations. There should be no pressure to identify with specific communities, or a specific set of core values of the nation, since cultural communities are characterised as well by vague internal boundaries, as by vague external boundaries. Identifications are never very strong, but neither are the pressures to assimilate or take on a specific cultural identity. Cultural belongings are, or ought to be based on individual liberty and voluntarism. This does not resemble the meting pot theory, but what is sometimes termed 
ethnic hyphenation. It is a vision within which 'every individual is free to choose her or his place within the ethnic mosaic' (Hartmann and Gerteis 2005, 229).

3. Fragmented pluralism emphasises that the social whole is dissolved into its component collective units. Identification and loyalties are directed towards subnational groups rather than towards the nation. Belonging to a more or less autonomous and discrete group is seen as essential, rather than as something voluntaristic. It is within the groups that group members find the substantial moral and cultural bonds; to a much lesser degree these are to be found at the macro level. However, at the macro-level the (in principle) culturally neutral state mediates between group claims, and ensures the respect for group rights and collective self-determination (Hartmann and Gerteis 2005, 230). This model is often considered to be the standard vision of multiculturalism, the opposite of cultural homogeneity and assimilation. However, as Hartmann and Gerteis remark, within this model assimilation at the macro-level is substituted for assimilation at the subnational level, or what they call segmented assimilationism (Hartmann and Gerteis 2005, 231)

4. Interactive pluralism is named as the cousin of fragmented pluralism. As within the latter, the existence of distinct groups and cultures is recognised and celebrated in and of themselves; subnational group belonging is seen as primary source of identity. But interactive pluralism differs from fragmented pluralism in two important aspects. Interactive pluralism 'stresses groups in action with each other mutually constituting the social whole' (Hartmann and Gerteis 2005,23 I). Secondly, this vision underlines the importance of cohesion at the macro-level as well, but as something emergent as the result of the interaction, or constant dialogue inside and between the different cultures within a decentred national framework. The moral bonds between groups within the social whole are constructed as a 'fusion of horizons', something constantly reinvented and reinterpreted within a more or less democratic interaction.

\section{The community: national and/or multicultural?}

The first part of my analysis focuses on two publications, produced by the Danish Ministry of Education, in the years 1999 and 2000. I intend to analyse these two texts together, since they both heavily bear the imprint of the social liberal Minster of Education Margrethe Vestager's ambitions to revive a public debate about sociocultural belonging and identity in Denmark. ${ }^{2}$

In 1999 the Ministry published a document called Education and community (Ministry of Education 1999). It claimed that 'we' were living in a transitional historical phase as a consequence of the dawning of 'the knowledge society'. The educational system faced two fundamental challenges: First, it had to make sure that the level of 'competences' of the Danish population was the best in the world. In this way the Danish welfare society could be developed and improved. Secondly, the educational system had to make explicit 'the values' that could strengthen 'the community'. It was important, the Ministry pointed out, that young people within contemporary 'zapping society' were retained within the community, 'where the problems must be solved' (Ministry of Education 1999, 2). It was in connection with this normative aspiration that the concept of citizenship for the first time was used as part of official Danish educational discourse:

... the educational system must strive to give new life to the concept of citizenship, in that we by the notion citizen mean the empowered person that feels obliged to engage in the life of fellow human beings and the community. It is within the community that we learn to handle the problems and crises that occur. Personal freedom is not meaningful until you are part of a community. (Ministry of Education 1999, 2)

Thus, citizenship education was expected to establish the normative point of reference in an effort to sustain responsibility towards democratic values. She didn't in any detail spell out 
which democratic values she had in mind. And she didn't explain what she meant by using the notion of citizenship. However, the Danish society was not only facing the challenges of maintaining democratic values in the knowledge society.

We are developing a multicultural identity in Denmark. That doesn't mean that we lose a Danish identity, but that the Danish identity develops and becomes something different than it was - as it has always done. The Danish educational system has to open up to the world in order make us conscious about the fact that our welfare depends on the rest of the world, so that we can understand and respect other cultures. (Ministry of Education 1999, 4)

Margrethe Vestager didn't explicate what exactly she meant by 'a multicultural identity', or how this identity might, or might not, contribute to the loss of 'a Danish identity'. She indicated a possible tension between on the one hand what was termed in indefinite singular ' $a$ Danish identity', or ' $a$ multicultural identity', and on the other what she termed in definite singular as 'the Danish identity', 'the community'. This tension, and its possible reconciliation, was, perhaps deliberately, rather vaguely stated, since precisely this tension was taking centre stage within public debates in Denmark at the time of publication. At the level of high politics there was growing popular support for the Danish nationalistic party The Danish People's Party, who had launched a fierce criticism of the reluctance of the established political elite to take action against the development of a multicultural Denmark. But Vestager also indicated her position within this tension, when she argued that despite the fact that we were developing a multicultural identity, 'other cultures' were something that 'we can understand and respect'. Apparently the national community was intact, at least it still constituted the taken-for-granted interpretative framework within which 'we' could observe and understand a rapidly changing world and a potentially emergent multicultural identity.

\section{Reinventing national citizenship}

Just one year later, in the year 2000, Margrethe Vestager and the Ministry of Education offered some clarification regarding the vagueness and tensions between the national and/or multicultural identity of 'the community', which makes it a bit easier to position her within the model of multiculturalism. She published a document called Values in practice (Danish Ministry of Education 2000) that elaborated on and continued some of the arguments launched in Education and community. Processes of globalisation, individualism, valuing pluralism, and the de-traditionalisation and disembedding of late modern life from previous sociocultural identities and institutional bonds were taking place with increasing speed, Vestager claimed. 'Nothing is given any more', she noted, not even the power of the nation state (Danish Ministry of Education 2000, I8).

This situation presented new urgent dilemmas that had to be confronted. On the one hand she acknowledged that 'Danish cultural concepts and value patterns had been positively challenged and enriched'. On the other she could observe the danger of political, social and cultural disorientation, as well as normative nihilism, as a potential outcome of this situation. What was supposed 'to bind us together', Vestager asked, what might ensure the sociocultural, moral and political cohesion of the Danish society? (Danish Ministry of Education 2000, 20)

According to Hartmann and Gerteis's analytical framework Vestager drew on two versions of multiculturalism. On the one hand she concluded that 'it's all about getting a dialogue established on equal terms' - 'it is in dialogue that children express themselves about everything and become part of the community'. She emphasised that in the future the Danish educational system should be characterised by 'openness and inclusiveness' that would leave room for pupils of 'another ethnic background'. And she stated that it would be wrong if 'we in Denmark tried to force a uniform Danish nationality on everybody'. It is all about offering these pupils (of another ethnic background) 'elements of the Danish identity which are so essential that they 
can feel at home in Danish society without any difficulties' - and 'it should be done in full consideration of their own cultural values' (Danish Ministry of Education 2000, 39).

The relations between cultural groups and the national community should be based upon an open and power free intercultural dialogue or communication, within the normative framework of the long established inclusive democratic values of the Danish society in general, and of the Danish educational system in particular. The values would be the same as for the past $100-150$ years, Vestager wrote, such as intellectual and spiritual freedom, tolerance, freedom of expression and other political rights (Danish Ministry of Education 2000, 7). In this sense she promoted mutual recognition and respect of difference, which according to Hartmann and Garteis are two of the central features of interactive pluralism. Democratic citizenship education should lead to a relatively thick substantive form of social cohesion, but how those representing other ethnic backgrounds relate to the community and its values was seemingly a question of negotiation and 'democratic hermeneutics' - something in the state of becoming. Hartmann and Gerteis $(2005,232)$ emphasise that within theories of interactive pluralism, there is a decentred vision of the national culture, the macro-culture being constantly redefined, the overarching community is something 'emergent', and it is constructed as a result of the interaction of different groups. All this corresponds neatly to the ways in which Vestager analysed the dis-embedded nature of late modern society. There are substantive normative commitments, but even these commitments evolve to some extent as a result of an intercultural 'fusion of horizons'.

But in at least in two ways she departed from this model. The first had to do with the way she defined 'solidarity', which was another fundamental value of Danish society. She warned that solidarity was not to be confused with welfare benefits. Instead she proposed that in order to understand what solidarity really is, we should take our point of departure "in our human and Christian heritage, also gather these values under the designation of "love your neighbour" (Danish Ministry of Education 2000, 37). The second element that signalled a break with the interactive model is concerned with the way she understood national identity.

The Danish education system must continue to be Danish with the characteristics that are typical for it. The school offers the pupils knowledge about our culture, literature, history and the development of society. Here, the language - the mother tongue - plays a fundamental role. It is through the mother tongue that we make our history, traditions and myths about ourselves, our people and its history come alive. The language is in itself a living symbol of the community. It links us together across social and age barriers. We contribute to keeping it alive ourselves; we are all part responsible for how it develops. When we were children, we hurt our knees in Danish, we were comforted in Danish, we were given our first kiss in Danish, and we had love troubles in Danish. At school we felt sorry for the ugly duckling in Danish, we shivered at the thought of schoolmaster Blomme in Danish and laughed our heads off at the Olsen Gang in Danish. They are all memories which make up a major part of our very identity. They are in our hearts and are based on our mother tongue. (Danish Ministry of Education 2000, 18)

On the one hand Vestager advocated intercultural dialogue and respect of cultural diversity, on the basis of what was claimed to be inclusive democratic 'universals' of Danish society. On the other hand she indicated that these values were intimately linked to a seemingly undisputed ethno-religious essence of the Danish nation. After all, neither the democratic values, nor the overall cultural foundation of the Danish nation were seen as a result of interactions between groups or cultures within the multicultural Danish democracy. Democratic citizenship and the ethno-cultural identity of the Danish nation seemed to enter a symbiosis; the identities of citizenship education were neither 'emergent' nor an intercultural 'fusion of horizons'. This might explain why she used phrases in definite singular - the history, the tradition, the community, and terms like 'our culture' and 'our Christian cultural heritage' and so forth. In this perspective the core of Vestager's citizenship education pointed as much in the direction of what Hartmann and Garties term assimilationism as in the direction of interactive pluralism. The 
overall aim of citizenship education pointed in the direction of a cultural and normative core of the social whole which was equal to the mono-cultural Danish nation. If such a national community existed it is hard to imagine how 'outsiders' could be full inside members, if they didn't to a large extent assimilate. At least it was difficult to see how and why 'outsiders' should enter an intercultural dialogue if the exclusive and mono-cultural definition of national identity was an undisputed hegemonic reality.

\section{Citizenship education as integration policy}

One of the central and highly profiled ambitions of the Danish liberal-conservative government that came into office in $200 \mathrm{I}$ was to deal with the challenges of immigration in a stricter and more consequential manner than what the government considered to have been the case for several decades. The Ministry of Refugee, Immigration and Integration Affairs was established in order to streamline and centralise integration issues as a field of political intervention. It is in this connection that the use of the concept of citizenship was further introduced and elaborated as an element of official educational discourse. In June 2003, a group of ministers within the government submitted a report, which they called The government's vision and strategies for improved integration. The political importance of this endeavour was immense, since it was meant to involve several powerful ministries within the Danish nation state: The Ministry of Education, The Ministry of Culture, The Ministry of the Interior, The Ministry of Integration, The Ministry of Social and Equal Opportunities and The Ministry of Occupation.

Another indication of the importance of this document was that the Liberal Party, the Conservative Party, and the Danish People's Party in their election campaigns had promised to take action in relation to what was considered to be the still more problematical and potentially dangerous consequences of further immigration, and in particular the development of a multicultural Denmark. The election was historically exceptional, in that 'the multicultural questions', or perhaps more correctly, 'problems of integration', had never before dominated the political discourse to such an extent. What was needed, a majority claimed, were harsh restrictions on immigration, and a re-vitalised and strengthened policy of integration in order to ensure the social and moral cohesion of the Danish nation state. Both issues, they claimed, had been severely neglected by the centre-left political, cultural and intellectual establishment - this was due to their political correctness, their hazardous embracing of value pluralism and their cosmopolitanism. Therefore, the integration policies that followed the liberal-conservative power take over, strongly supported by the Danish People's Party, were launched as part of a more complex and fundamental normative struggle against the quarters of the establishment who were more or less explicitly and naively in favour of expanding cultural diversity within Danish society.

The report was considered to pinpoint 'a new course' in Danish integration policies that would rest on 'some fundamental principles', as an effort to ensure:

... a coherent and open democratic society within which basic values are that citizens demonstrate responsible citizenship, and an active respect for the values, that are fundamental within a free and democratic welfare society, containing room for difference and individual freedom. (Regeringen 2003, 8)

Integration into the Danish welfare society was outlined within a double-edged vision of two interconnected strategies: practical enrolment into the educational system and into the workforce, and, at the same time, the acquisition of and commitment to citizenship values. Citizenship in the broad sense, and citizenship education in particular, were the normative threads of the report. The Ministers' understanding of citizenship was not restricted to formal liberal rights and duties, and the aims of citizenship education were not restricted to the transmission of formal skills, knowledge and competences. Rather, citizenship education was meant to ensure that the 
'basic values' of Danish society were maintained and transmitted to 'them' - those coming from the outside. And it was outlined that citizenship education was a lifelong learning process. The normative intentions of, and the sociocultural background for, citizenship education were described in this way:

In the following a lot will be written about our 'values'. This means the basic broadmindedness, which stems from respecting human beings and the particularity of each individual. And it means our concept of democracy, which contains more than a majority rule ... newly arrived foreigners have to learn these values, and these values have to be respected. ... The fundamental point of view is that foreigners who come to live here should learn about our often different point of views, and they should respect the society, which they are to be a part of. But, naturally, we who belong to the majority have to exert ourselves to understand other cultures and other outlooks on life. (The government's vision and strategies 2003, 6)

The foundational values of the society are challenged, both because new citizens offend against them, and because other parts of the population do it. This happens for instance in connection with the circumcision of girls, forced marriages, and when somebody is expelled from work because of their colour, their conviction or because a Muslim woman wants to wear a headscarf. (The government's vision and strategies 2003,8 )

Efforts to improve integration into the Danish society were explicitly connected to a majority 'we'. The opposition, or rather the antagonism to this 'we' was the 'they' who offended 'our values'. Even though it was stated that foreigners were supposed to learn about 'our often different viewpoints', a cultural homogenous national majority community never the less was taken for granted as representing the normative consensus into which 'they' could and should be incorporated. 'They' were supposed to learn the ways to respect and live in accordance with the fundamental values and norms of 'our' democratic citizenship.

But it was not groups as such that were supposed to integrate. Several times it was underlined that 'the individual contributes as an active citizen' and that the purpose of improved integration was to ensure 'the best conditions possible with regard to individual growth' (The government's vision and strategies 2003, 7-8). The Danish society was expected to make room for 'difference' and 'freedom', and 'we' were assured that the Danish society needed immigrants and refugees. But it was underlined that it was the 'competences of the individual' which was needed. Furthermore, it was pointed out that the Danish society should make room for religious and cultural exposition, but it was 'the individual' that was supposed to contribute as an active citizen, and it was a question of showing 'respect for the individual'.

The government did not consider communal cultural diversity, or the interaction of the intermediate groups as a positive contribution to or even as something that could expand the quality of Danish society's democratic citizenship values. 'We' were supposed to try 'to understand other cultures', 'we' were not supposed to recognise or value their existence - only positively to value individuals. There wasn't much talk about 'their' rights, but quite a lot was stated about their obligations towards 'our' notion of democratic citizenship. The collective norms or traditions, such as forced marriages or circumcision of women, of the people arriving 'here' were mentioned as something primarily problematic or out of bounds in terms of 'our' values. In the light of Hartmann and Gerteis's analytical framework the combination of citizenship education and integration policy could be interpreted as based on two versions of multiculturalism. On the one hand 'we' - the Danish nation - and 'the others' seemed to belong to more or less autonomous and discrete groups. It seems to be within the groups that group members find the substantial moral and cultural bonds that bind them together. In that respect the government promotes fragmented pluralism. But on the other hand the government underlined that it was the individual that has to integrate, and that the individual had to get rid of norms and values that could be traced to their original cultural or religious belongings. And it was also stated that 
the integration had to do with the incorporation of individuals into the social whole which rests on a collectively based normative core of democratic citizenship. In this sense the hegemonic idea of integration plan is assimilationism.

\section{Democracy blindness}

As mentioned in the introduction, the legal framework of the new subject of teacher education is formulated in very general terms. For instance the description of the new subject is only vaguely connected to the use of a multicultural terminology. But we have one document that does expose some of the multicultural thinking behind the initiative. In 2006 the Danish Ministry of Education published a White Paper called Democracy (Danish Ministry of Education 2006). In this paper the liberalist Danish Minister of Education, Bertel Haarder, mentioned the plans for a new subject as part of a reform of the teacher education. ${ }^{3}$ The reason for this, the Minister claimed, was that each generation suffers from its own version of democracy blindness; every generation has to reinvent democracy. Therefore 'we' have to teach the fundamental concepts of democracy. The primary school ought to be the democratic meeting point of children with different social and cultural backgrounds.

But the students were not only expected to learn about democracy, they were also expected to learn to behave as 'citizens' and to 'understand the value of active citizenship'. The value of citizenship and democracy were interpreted as an integral part of a popular national and historical narrative about how 'our democracy' had successively been extended. The interesting question is why it seemed to be a pressing obligation to fight democracy blindness at the time of publication. According to an interview with the Minister, democracy blindness is a general problem within Danish youth.

We can observe that a rising number of young people don't have a clear concept about democracy, and that create problems that have surprised al of us. This does not only concern immigrants, but also Danish children. They suffer democracy blindness, simply because they don't know enough about it. ... In the 1930s and 1940s we experienced influences for instance from Germany and Italy, where Danish intellectuals were blinded by strong leaders. In the 60s and 70s it was the blindness caused by communism, where the colour scraps of dictators influenced Danish universities and high schools. (Danish Ministry of Education 2006, 25)

Therefore, the implementation of citizenship education within teacher training was regarded as a prolonged historical struggle against authoritarian political ideologies. The Minister was of the opinion that today we experience young people who think that their religion is at odds with democracy, which it isn't. The paper contained what was supposed to figure as illustrative examples of the ways in which democracy blindness is dealt with at different levels of the Danish educational system. These examples were meant to be a source of inspiration for teachers and school principals. What is also interesting to note is that almost all of these examples are related to multicultural and especially religious schools. This could be interpreted in a positive vein: The interaction of different cultural groups within the Danish educational system are supposed to be the progressive front figures in order to develop and sustain democratic citizenship in the future. In that sense the White Paper supported interactive pluralism.

Another interpretation is that the multicultural youth, in particular (fundamentalist) Muslims, represent the expanding democracy blindness in Denmark. That might explain why 'citizenship' figures as one element of the new teacher training subject, alongside Christianity studies and life enlightenment. The hidden message was that the educational system was mobilised in order to combat religious extremism - especially Muslim fundamentalism. What is also relevant to note, is that the Minister of Education didn't make an argument for a secular state or a secular school system. That is why, he remarked, Christianity is still an integrated part of the curriculum of the 
Danish primary school, and figures as an element of the new teacher training subject. Viewed from this perspective the White Paper confirmed the link between democratic citizenship and the Christian identity of the Danish nation. In other words the citizenship agenda of the new subject of Danish teacher education is assimilation of Muslims and the ethnic 'others' into the Christian Danish nation.

\section{Conclusion}

I have used a four-dimensional model of multiculturalism to analyse the ways in which the Danish nation state combines discourses of citizenship education and multiculturalism. The model was meant as a heuristic categorisation. My expectation was not that the data of my discourse analysis would fit smoothly into the categories. Rather, the discourse of the four documents fits parts of the model as a matter of degree. However, one hegemonic tendency was that multicultural Danish society is constituted as a relation between a social whole, which is equal to the Danish nation and 'the cultural other'. The former is described and specified mostly in positive terms, the cultural characteristics and collective identities of the latter are either very vaguely specified and recognised, or mostly designated as a thread to the normative and cultural centre of Danish nation. I find it reasonable to conclude that the Danish nation state uses a discourse of citizenship education to conduct assimilitionism. As envisioned by the Danish nation state, citizenship education means absorption of de-culturalised individuals into a presumably homogenous sociocultural identity and inner normative core of the democratic Danish nation. On several occasions the present Danish Minister of Education, Bertel Haarder, has made statements that confirm this strategy of multiculturalism and identity politics.

Love of homeland is something universal, which cannot and should be wiped out ... nationalism and feeling of nationality are not only necessary evils, but constitute ... the fundamental substance without which moderns democracies cannot exist. The peoples want their homeland, where they decide for themselves and exercise shared responsibilities through democratic institutions. (Haarder 2005, 18)

I can also conclude that some elements of interactive and fragmented pluralism are articulated within the documents, while a vision of cosmopolitan multiculturalism is absent. Time will show whether the new subject of Danish teacher education will be practised in the light of one or several of these approaches to multiculturalism. What we could hope as the minimum is that proponents of the different visions and discourses of multiculturalism get into a fruitful, but not necessarily a non-conflictual, dialogue with each other. To pursue assimilationism is a legitimate agenda of citizenship education. However, in a multicultural democracy, I think it is crucial to note and articulate that there are alternatives.

\section{Notes}

I. The specification and description of the content of the new subject is a local matter, which means that it is in the hands of the individual teacher training college. However, the plans for the new subject have to be approved by the Ministry of Education.

2. Margrethe Vestager was Minister of Education 1998-200I.

3. Bertel Haarder was Minister of Education 1982-1993, Minister of Integration and Development 200 I-2005, and once again Minister of Education from February 2005, a position he still holds at the time of writing.

\section{Notes on contributor}

Claus Haas is Assistant Professor in the Department of Educational Anthropology at the Danish School of Education, University of Aarhus. 


\section{References}

Alibhai-Brown, Y. 2000. After multiculturalism. London: The Foreign Policy Centre Brubaker, R., and F. Cooper. 2000. Beyond 'identity'. Theory and Society 29: I-47.

Danish Ministry of Education. 1999. Uddannelse og fællesskab [Education and community]. Copenhagen: Danish Ministry of Education.

Danish Ministry of Education. 2000. Values in practise. Copenhagen: Danish Ministry of Education.

Danish Ministry of Education. 2006. Democracy. Copenhagen: Danish Ministry of Education.

Delanty, G. 2003. Community. London: Routledge.

Haarder, B. 2005. Fremtidens pris. In Danmark på vej mod år 2020, ed. A. Heick. København: Tidernes Skifter.

Haas, C. 200I. Active citizenship in a multicultural perspective. In Learning for democratic citizenship, ed. O. Korsgaard, S. Walters, and R. Andersen. Copenhagen: Association for World Education and Danish University of Education.

Hall, S. 2000. Conclusion: The multicultural question. In Un/settled multiculturalisms. Diasporas, entanglements, transruptions, ed. B. Hesse. London: Zed Books.

Hartmann, D., and J. Gerteis. 2005. Dealing with diversity: Mapping multiculturalism in sociological terms. Sociological Theory 23, no. 2: 218-40.

Kanpol, B., and P. McLaren. 1995. Critical multiculturalism. Uncommon voices in a common struggle. Westpoint, CN: Bergin and Garvey.

Parekh, B. 2000. Rethinking multiculturalism. Cultural diversity and political theory. London: Macmillan.

The Parekh Report. 200I. The future of multi-ethnic Britain. London: Runnymede Trust.

Regeringen. 2003. Regeringens visioner og strategier for bedre integration [The government's visions and strategies for improved integration]. Regeringen: Copenhagen. 